UDC 930.85

DOI: $10.24045 / \mathrm{pp} .2017 .1 .7$

\title{
DIPLOMATIC RELATIONS IN EARLY ISLAMIC PERIOD
}

N. K. Ibragimova
Doctoral applicant

Tashkent Islamic University

Tashkent, Uzbekistan

\begin{abstract}
This article observes the diplomatic relations of Prophet Muhammad and his activity on foreign affairs of the Islamic state in Madinah. The complex of the publication covers completely diplomatic methods of the Prophet on peace treaties like sending ambassadors and their receptions in initial stages board, also the signing of the Madinah's Constitution and the treaty of Hudaybiyya. As well as in this article there are given the correspondence of the Prophet with other leaders such as Heraclius, Chosroes, Negus, Al-Muqawqas, Mundhir bin Sawa and others. The demands of the Prophet Muhammad to ambassadors were considered in it.
\end{abstract}

Keywords: Diplomatic relations; ambassadors; capacities; possibilities; year of ambassadors; visit; peaceful way.

The foreign affairs of the government are a special form of the social activity. Diplomacy means the complex of activities in collaboration of members in various spheres of international relations. Likewise diplomacy includes all remedies which fix the relations, safe them and achieve an agreement.

Ambassador is the main and important person who directs diplomatic relations. For the symbol of trust he is a respectable person in other countries too.

Ambassadors are in the centre of attention in Islamic teachings too. Prophet $\mathrm{Mu}$ hammad was the Messenger of the Islamic religion. His duties were like the functions of ambassadors. He had to message just the truth. The meanings "ambassador and messenger" differ in their consequences. They are used in religious and political consequences. In Holy Qur'an it is written about functions of messengers:

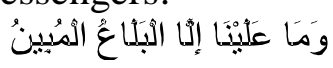

And our duty is only a clear deliverance (of the message) (to proclaim the clear Message) [2, p. 36-17].

The Prophet Muhammad was demanded underpointed capacities of ambassadors:

1. Polite and eloquent

2. Healthy
3. Oratory

4. Forcible

5. Forceful

6. To know the language of an arrived country.

Major Islamic scientists assert that $\mathrm{Mu}-$ hammad selected a number of noble companions to be his ambassadors to kings and rulers. For this purpose he chose people who had deep knowledge, outstanding intelligence, good reputation, good looks and eloquent speech that would be influential.

If an ambassador arrived to an Islamic country as a member of his motherland, it would be forbidden to kill and to force him. The words of Muhammad to two ambassadors of Musaylama Cheat can be as an argument: "If it was possible to kill ambassadors, I was murder you myself" [1]. On this base, protection of ambassadors is considered one of the great Sunnah in Islam.

There is a conception "Aman" in Sharia, which non Muslim people except ambassadors can apply to defend their life and property. In early Islamic period there were underpointed possibilities for ambassadors:

- Life and property immunity;

- Freedom of religion and conscience; 
- Freedom of customs and others.

When Muhammad arrived in Madinah in 622, he established the Constitution, which named "Manshuru Madinah". This document regulated interactions between people of Mecca and local tribes like Banu Aus, Banu Khazraj. Ruling in Madinah was a different role for Muhammad, because he had to unit community of Yasrib. It was the great pact, which fixed civil and political relations of the citizens. Bernard Lewis said that this community became a new kind of tribe like $\mathrm{Mu}$ hammad having a religious character [7]. But Watt refused opinion of Lewis about $\mathrm{Mu}$ hammad's authority and said that he was just the religious Leader of Medina [10].

The signing of the constitution could be seen as indicating the formation of united community and federation of nomadic tribes. This pact itself displayed a degree of diplomacy by Muhammad. After increasing influence of Muhammad in Madinah, he decided to perform Umrah (lesser piligrimage) and this way the treaty of Hudaybiyya was signed. The treaty was set to expire after 10 years, but was broken after only 10 month.

After the Migration (Hijra) of Muslims to Madinah, and especially after Hudaibiyah Muhammad began to send his members to other countries in order to deliver the letters. Certain part of ambassadors was sent before Haybar Battle, another part after this event. It was narrated in "Sahih Al-Bukhari" like that: "Late in the sixth year A. H., on his return from Hudaibiyah, the Prophet Muhammad, decided to send messages to the kings beyond Arabia calling them to Islam. In order to authenticate the credentials of his envoys, a silver seal was made in which were graven the words: "Muhammad the Messenger of Allah" [6, p. 872, 873]. They were:

1. Dihya Ibn Kalbi to Heraclius, the Roman Emperor:

"In the Name of Allah, the Most Beneficent, the Most Merciful. From Muhammad, the slave of Allah and His Messenger to Hercules, king of the Byzantines. Blessed are those who follow true guidance. I invite you to embrace Islam so that you may live in security. If you come The letters of the prophet Muhammad 14 within the fold of Islam (If you accept Islam), Allah will give you double reward, but in case you turn your back upon $i t$, then the burden of the sins of all your people shall fall on your shoulders [6, 1/4,5]. "Say (O Muhammad [pbuh]): 'O people of the Scripture (Jews and Christians), come to a word that is just between us and you, that we worship none but Allah, and that we associate no partners with Him, and that none of us shall take others as lords besides Allah.' Then, if they turn away, say: 'Bear witness that we are Muslims" [2, 3:64]

2. Abdullah Ibn Huthaafah AsSahmi to Chosroes, King of Persia:

"In the Name of Allah, the Most Beneficent, the Most Merciful. From Muhammad, the Messenger of Allah to Chosroes, king of Persia. Blessed are those who follow true guidance, believes in Allah and His Messenger and testifies that there is no god but Allah Alone with no associate, and that $\mathrm{Mu}$ hammad is His slave and Messenger. I invite you to accept the religion of Allah. I am the Messenger of Allah sent to all people in order that I may infuse fear of Allah in every living person, and that the charge may be proved against those who reject the Truth. Accept Islam so that you may live in security, otherwise, you will be responsible for all the sins of the Magians".

3. Amr Ibn Umayya Adh-Damri to Negus, the King of Abyssinia:

Al-Baihaqi, on the authority of Ibn Ishaq, gave the following narration of the Prophet's letter sent to Negus: "This letter is sent from Muhammad, the Prophet to Negus Al Ashama, the king of Abyssinia (Ethiopia). Blessed are those who follows true guidance and believes in Allah and His Messenger. I bear 
witness that there is no god but Allah Alone with no associate, He has taken neither a wife nor a son, and that Muhammad is His slave and Messenger. I call you to the fold of Islam; if you embrace Islam, you will find safety,

"Say (O Muhammad): 'O people of the Scripture (Jews and Christians), come to a word that is just between us and you, that we worship none but Allah, and that we associate no partners with Him, and that none of us shall take others as lords besides Allah.' Then, if they turn away, say: 'Bear witness that we are Muslims.' " [2, 3:64] If you reject this invitation, then you will held responsibility for all the evils of the Christians of your people".

4. Haatib Ibn Abi Balta'ah to AlMuqawqas, the ruler of Egypt:

"In the Name of Allah, the Most Beneficent, the Most Merciful. From Muhammad slave of Allah and His Messenger to Muqawqas, vicegerent of Egypt. Blessed are those who follow true guidance. Thereafter, I invite you to accept Islam. Therefore, if you want security, accept Islam. If you accept Islam, Allah, the Sublime, shall reward you doubly. But if you refuse to do so, you will bear the burden of the transgression of all the Copts".

5. Al-'Ala' bin Al-Hadrami to Mundhir bin Sawa, Governor of Bahrain:

"In the Name of Allah, the Most Beneficent, the Most Merciful. From Muhammad, Messenger of Allah to Mundhir bin Sawa. May peace be on you! I praise Allah with no associate, and I bear witness that Muhammad is His slave and Messenger. Thereafter, I remind you of Allah, the Mighty, the Glorious. Whoever accepts admonition does it for his own good. Whoever follows my messengers and acts in accordance with their guidance, he, in fact, accepts my advice. My messengers have highly praised your behaviour. You will continue in your present office. Give the new Muslims full chance to preach their religion. I accept your recommendation regarding the people of Bahrain, and I pardon the offences of the offenders; therefore, you may also forgive them. The people of Bahrain who want to go on in their Jewish or Magian faith, should be made to pay Jizya (poll-tax)." [3. 3.p. 61, 62].

6. Amr Ibn Al-Aas to the two rulers of Oman.

"In the Name of Allah, the Most Beneficent, the Most Merciful. From Muhammad bin 'Abdullah to Jaifer and 'Abd AlJalandi. Blessed are those who follow true guidance; thereafter I invite both of you to the Call of Islam. Embrace Islam. Allah has sent me as a Prophet to all His creatures in order that I may instil fear of Allah in the hearts of His disobedient creatures so that there may be left no excuse for those who deny Allah. If you two accept Islam, you will remain in command of your country; but if you refuse my Call, you've got to remember that all your possessions are perishable. My horsemen will appropriate your land, and my Prophethood will assume preponderance over your kingship." [3. 3, p. 63].

The scientists differed the amount of ambassadors who were sent by our Prophet. Badriddin Ayni, the author of the comments on "Sahih Bukhari" said that they were six. But the author of "Zadulmaod" Ibn Qayyum said that they were eight. He added two ambassadors such as Aloi Khodrami and Amr ibn Os [3, p. 154]. Ibn Hishom mentioned these two companions too [4]. Muhammad Hamidullah noted that the letters had been sent to eleven rulers and he abbreviated their texts in his book [8].

The activity of Prophet on foreign affairs began in 622 after the Migration (Hijrat) of Muslims to Madinah. Two factors were the reasons to arrange these communications. They were:

1. Preach of Prophet Muhammad to a new religion independently; 
2. Noticing of "New created government" to countries around.

After sending ambassadors with Prophet's letters to the eight greatest rulers of that time there were various treatments as positive and negative. Some of them received his invitation and became Muslim such as the ruler of Negro (Najjoshi), another one respected the ambassador of the Prophet and cooperated, but did not receive Islam as his own religion as the ruler of Egypt (Muqavqis), others were categorically against such as the ruler of Persia (Kisro).

After the conquest of Makkah Prophet Muhammad received more than 20 ambassadors from independent tribes and countries around. That's why in Islamic history this year was named "Year of ambassadors" [4, p. $213 ; 7 ; 5]$. These events were in the IX-Xth years from Hijra.

If we analyze this condition, we can conclude that the ambassadors visited Prophet Muhammad on several aims like:

1. In order to seek the Great Trust and real faith. Also to recognize Prophet $\mathrm{Mu}$ hammad better.

2. To check Prophet Muhammad in a real aspects of Doomsday's Messenger.

3. Visit of ambassadors before occupation of countries in order to be a part of Islamic state without war and to come to the agreement with them.

4. To enter the peace relation after occupation and determine the sum of taxes.

5. Visit of ambassadors in radical intentions (intended murder).
The base of diplomacy is peace. The Islamic theology based on peace relations too. That's why Prophet Muhammad every time fixed the relations on diplomacy and resolved the problems in peaceful way.

\section{Bibliography}

1. Al-mavsuat al-hadisiyati. Musnad al-imhai alAhmad ibn Ahmad (164-241). - Bayrut: Muassasat al-risala, 1416/1995. - J. 3(487-488). Hadis was sent by Na'im ibn Mas'ud al-Ashjaiy in this literature and it is one of the reliable hadises.

2. English translation of the Holy Quran by Maulana Muhammad Ali.

3. Ibn Qayyum al-Javziya. Muhtasar zad al-ma'ad fi hadyi hoyri al-ibad. -Bayrut-Saydo: Al maktabatu al-asriya, 1424/2003. - S. 232.

4. Ibn Hishom. As-siyratu an-nabaviyyu. - J. 4. Bayrut-Lubnan: Dar ihyai at-turasi al-arobiyyi, 1417 /1997. 4/254. - S. 262.

5. Ibn Asir. Al-Kamil fit- tarih. - J. 2. - Bayrut: Dar ul-fikri, 1398/1978. - S. 142.

6. Imam al-Hafiz Ahmad Ibn Ali Hajr Al-Asqoloni. Fathul Bari sharhu Sahih al-Bukhari. -Riyaz: Dar us-Salam, 773-852. 13 Parts.

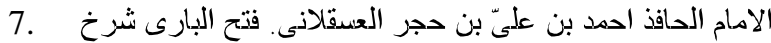

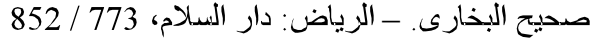

8. Lewis, Bernard. The Jews of Islam. US: Princeton University Press, 1984. ISBN 0-691-05419-3.

9. Muhammad Hamidullah. Al-vasaiq as-siyasiya (lil ahdi an-nabaviyi val-hulafai ar-roshida). Bayrut-Lubnan: Dar an-nafais, 1422/2001. S. 99-161.

10. Muhammad Sodiq Muhammad Yusuf. Hadis va Hayot - J. 19. - T. : Sharq, 2006. - B. 440.

11. Watt, M Montgomery. Muhammad: Prophet and Statesman. - UK : Oxford University Press, 1974.

(C) Ibragimova N. K., 2017. 